\title{
Use of pectin in the storage of mangaba fruits (Hancorniaspeciosa Gomes) associated with refrigeration
}

\author{
Plácido, G. R. ${ }^{1 \star}$, Silva, R. M. ${ }^{2}$, Cagnin, C. ${ }^{2}$,Silva, M. A. P. ${ }^{1}$, Soares, J. C. ${ }^{4}$ and Caliari, M. $^{3}$ \\ ${ }^{1}$ Programa de Pós-Graduação em Zootecnia, Instituto Federal Goiano - Campus Rio Verde, Rio Verde, Goiás, Brazil. \\ ${ }^{2}$ Food Engineering Course, Instituto Federal Goiano - Campus Rio Verde, Rio Verde, Goiás, Brazil. \\ ${ }^{3}$ Programa de Pós-Graduação em Ciencia e Tecnologia de Alimentos, Depatamento de Agronomia e Ciencia e \\ Tecnologia de Alimentos, Universidade Federal de Goiás, Goiânia, GO, Brazil. \\ ${ }^{4}$ Programa de Pós-Graduação em Ciencia e Tecnologia de Alimentos, Depatamento de Agronomia e Ciencia e \\ Tecnologia de Alimentos, Universidade Federal de Goiás, Goiânia, GO, Brazil.
}

Received 24 February, 2015; Accepted 31 August, 2015

\begin{abstract}
The objective of this study was to evaluate the storage potential of mangaba fruits coated with pectin biofilm stored in biochemical oxygen demand (BOD) $\left(22 \pm 1^{\circ} \mathrm{C}\right)$ under modified atmosphere. Scanning electron microscopy (SEM) was used to analyze the physical and chemical changes, vitamin $C$ content, soluble solid, titratable acidity and turgor pressure, and colour and physical structure of the fruits during storage. The physico-chemical and colour analyses of the fruit were done with four treatment groups: control and pectin solutions of 4,6 and $8 \%(w / v)$ at three day intervals for two weeks. The pectin solution and BOD were effective for the conservation of soluble solids of mangaba. However, the levels of acidity, vitamin $\mathrm{C}$ and turgor pressure showed that the fruits got ripe during the study and were kept until the sixth day of the test compared to control fruits. The best results were determined for the mangaba coated with 6 to $8 \%$ pectin.
\end{abstract}

Key words: Conservation, film solution, post-harvest, firmness.

\section{INTRODUCTION}

Mangaba (Hancornia speciosa Gomes) is a fruit appreciated for being consumed "in natura", is used in the manufacturing of food products such as drinks, ice cream, jams, compotes and in preparing wine and vinegar (Machado et al., 2004). In addition to the use of the fruit, the tree can also be exploited for the production of rubber; it is used as waterproof fabrics in Brazilian
Cerrado, for fabricating balls and treating dislocations and hypertension (Machado et al., 2004). It has considerable potential for industries, in the processing of juices, liquor and ice creams (Sampaio and Nogueira, 2006).

Mangaba fruit has ellipsoid and fleshy form, with greenish yellow colour and diameter of $3.4 \mathrm{~cm}$ (Ganga et 
al., 2010). It has white, acidic, fragrant and tasty pulp, with flat seeds and light brown colour (Vieira Neto, 2009). In Brazil, the species is distributed from North to the Midwest; it is grown in sandy soils with acid and low nutrients found in rocky slopes (Machado et al., 2004).

The fruit has interesting features such as good digestibility and high nutritional value due to its considerable contents of protein and vitamin C (Carnelossi et al., 2009). The agricultural exploitation of mangaba is limited due to its high perishability index and short harvest period, in addition to its mechanical, physical and microbiological damages (Soares et al., 2012).

Post-harvest fruit quality is related to the maintenance of color, firmness and appearance (Santos et al., 2009), which contributes to increased shelf life and greater consumer acceptance. The use of low storage temperature contributes to reductions in oxidative reactions, respiration and ethylene production, thus increasing the product durability (Campos et al., 2011).

The durability of fruits can be increased with the use of films for coating of fruits; this increases their protection (Corrêa, 2011). Pectin gel is an alternative for coating fruits and has the function of providing firmness, retaining aroma and flavour and playing the role of hydrocolloid in dispersions (Paiva et al., 2009).

From this assumption, the aim of this work is to study the storage potential of mangaba fruits coated with pectin biofilm stored in biochemical oxygen demand (BOD) (22 $\mathrm{C} \pm 1^{\circ} \mathrm{C}$ ) under modified atmosphere. It also aims to evaluate the physicochemical changes, colour and physical structure of the fruit.

\section{MATERIALS AND METHODS}

Mangaba fruits homogeneously cultivated in the region of Caçu-GO $\left(18^{\circ} 33^{\prime} \mathrm{S}\right.$ and $\left.51^{\circ} 08^{\prime} \mathrm{W}\right)$ were manually harvested in October 2013 and brought to the Laboratory of Fruits and Vegetables, Federal Institute of Goiás, Rio VerdeCampus - GO, Brazil. The fruits were selected by size, colour and absence of mechanical injuries. They were sanitized in chlorinated water for three minutes $(100 \mathrm{mg} / \mathrm{L})$. The fruits from the different treatments were kept in BOD with average temperature of $22 \pm 1^{\circ} \mathrm{C}$.

Mangaba fruits were immersed in pectin filmogenic, of mark Unipectine solutions (of $0,4,6$ and $8 \%$ (w / w) concentrations) for one minute. The pectin solution $(0,40,60$ and $80 \mathrm{~g})$ was solubilized in $1 \mathrm{~L}$ of distilled water at room temperature and homogenized in a blender for $30 \mathrm{~s}$ for gelation of pectin solution (0, 4, 6 and $8 \%$ ). Subsequently, they were placed in a suitable container to drainand dry the excess solution.

The treatments were stored in $150 \times 150 \times 18 \mathrm{~mm}$ Styrofoam trays in BOD and were evaluated every three days for fifteen days. The treatments were done in three replicates with five fruits each. The following parameters were evaluated by scanning electron microscopy (SEM): soluble solids (SS) and titratable acidity, ascorbic acid, turgor pressure, and color.

In determining the content of soluble solids expressed in ${ }^{\circ} \mathrm{Brix}$, the filtered juice was read in refractometer Atago N-2E according to AOAC method No. 983.17 (1992). Titratable acidity was determined by volumetric redox by titrating mangaba samples with 2,6 dichlorophenol-indophenol sodium solution (DCFI) according to AOAC method No. 967.21 (2000). The turgor pressure was determined by applanation technique using a horizontal applanator (Calbo and Nery, 1995) and results were expressed as $\mathrm{kgf.cm}^{-2}$.

The colour parameters $\left(L^{*}, a^{*}, b^{*}\right)$ of mangaba fruits were analyzed in Hunter Lab colorimeter model Colour Quest II at the Laboratory of Physicochemical Analysis, School of Food Engineering, Federal University of Goiás, Goiânia - GO, Brazil. The $L^{*}$ values (lightness or brightness) ranged from black $(0)$ to white (100), the $a^{*}$ values ranged from green $(-60)$ to red $(60)$, and the $b^{*}$ values, from blue to yellow on the same scale as the $a^{*}$ values.

The epicarp of mangaba fruits was removed and dried at $60^{\circ} \mathrm{C}$ for $12 \mathrm{~h}$ and stored in desiccator for further analysis by SEM. For this analysis,samples were placed on stabs, coated with a thin layer of gold and micrographed. Evaluation was performed at the Laboratory of Multiuser High-Resolution Microscopy, Institute of Physics - Federal University of Goiás, Brazil. Scanning electron microscope, Jeol, JSM -. 6610, equipped with EDS, Thermo scientific NSS Spectral Imaging was used.

The experimental design was completely randomized and the analysis of results was performed using $4 \times 6 \times 3$ factorial design consisting of four treatments (control and pectin solutions of 4,6 and $8 \%)$, six days of storage $(0,3,6,9,12$ and 15 days) and three replicates for each fruit tray. This results in nine replicates of each treatment and day of the study. The models were selected according to the coefficient of determination and their significance was determined through the $\mathrm{F}$ test. The averages obtained for analyses of total soluble solids, titratable acidity, ascorbic acid, turgor pressure and colour were compared by the Tukey test at 5\% probability, using the SISVAR software.

\section{RESULTS}

\section{Soluble solids content}

The soluble solid content of mangaba fruits was not significantly affected during storage with different percentages of pectin coating under controlled temperature. Table 1 shows that the fruits had an increase in soluble solids content up to the sixth day of storage, then a decrease on the ninth day and an increase again at the end of the analyses.

Figure 1 shows the differences in the SS content for control and treated fruits. In the present study, fruits coated with $4 \%$ pectin showed greater variation in the amount of soluble solids during storage and the lowest variation was observed for fruits with $6 \%$ pectin.

Regardless of the pectin concentration used in the coating of mangaba, it showed decreases and increases in soluble solids content during storage. The fruits with 4 and $0 \%$ pectin showed the highest variation in these levels. However, at the end of 0 days, the fruits remained with high soluble solids contents, except for fruits with $0 \%$ pectin, which showed decreased levels compared to the first and $15^{\text {th }}$ days of the analysis.

\section{Titratable acidity levels}

Mangaba fruits showed titratable acidity levels ranging from 0.028 to $0.172 \%$ citric acid (Table 2). Mangaba fruits coated with $8 \%$ pectin solution showed greater differences in the acidity index (Figure 2) compared to the control 
Table 1. Soluble solids content ( ${ }^{\circ}$ Brix) of mangaba fruits stored in biochemical oxygen demand (BOD) at temperature of $22 \pm 1^{\circ} \mathrm{C}$ and coated with pectin solution.

\begin{tabular}{ccccc}
\hline \multirow{2}{*}{ Days of storage } & \multicolumn{4}{c}{ Pectin solution concentration } \\
\cline { 2 - 5 } & $\mathbf{0 \%}$ & $\mathbf{4 \%}$ & $\mathbf{6 \%}$ & $\mathbf{8 \%}$ \\
\hline 0 & $9.93 \mathrm{aA}$ & $17.14 \mathrm{aA}$ & $10.89 \mathrm{aA}$ & $10.63 \mathrm{aA}$ \\
3 & $9.93 \mathrm{aA}$ & $17.14 \mathrm{aA}$ & $10.89 \mathrm{aA}$ & $10.63 \mathrm{aA}$ \\
6 & $12.32 \mathrm{aA}$ & $12.32 \mathrm{aA}$ & $10.34 \mathrm{aA}$ & $11.86 \mathrm{aA}$ \\
9 & $8.72 \mathrm{aA}$ & $8.97 \mathrm{aA}$ & $10.11 \mathrm{aA}$ & $10.11 \mathrm{aA}$ \\
12 & $13.57 \mathrm{aA}$ & $13.39 \mathrm{aA}$ & $14.77 \mathrm{aA}$ & $17.03 \mathrm{aA}$ \\
15 & $13.57 \mathrm{aA}$ & $13.38 \mathrm{aA}$ & $14.76 \mathrm{aA}$ & $17.03 \mathrm{aA}$ \\
\hline
\end{tabular}

Different lowercase letters in line significantly different between themselves and capital letters indicate significant differences between the columns using the Tukey test at $5 \%$ probability.

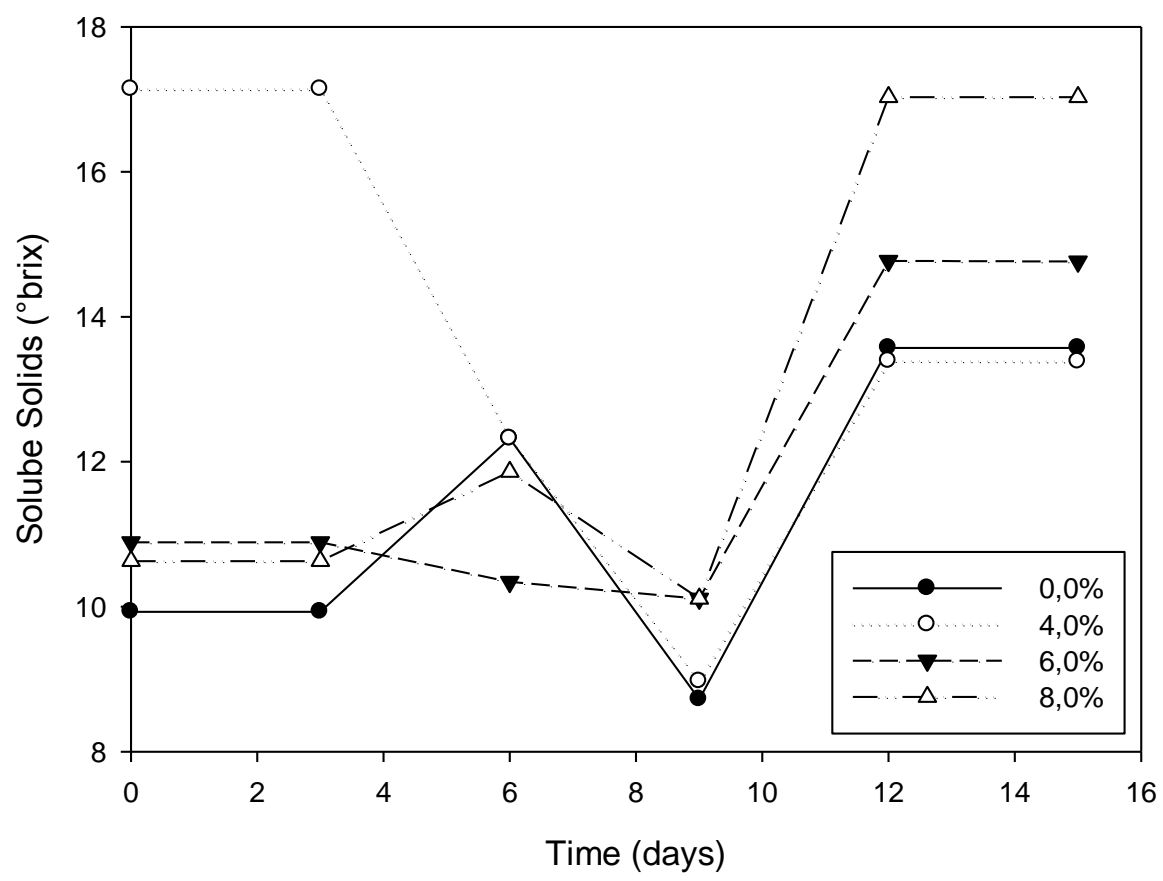

Figure 1. Soluble solids content for control and treatments during storage of mangaba fruits.

Table 2. Titratable acidity values for mangaba fruits stored in BOD at temperature of $22 \pm 1^{\circ} \mathrm{C}$ and coated with pectin solution.

\begin{tabular}{ccccc}
\hline \multirow{2}{*}{ Days of storage } & \multicolumn{4}{c}{ Pectin solution concentration } \\
\cline { 2 - 5 } & $\mathbf{0 \%}$ & $\mathbf{4} \%$ & $\mathbf{6 \%}$ & $\mathbf{8 \%}$ \\
\hline 0 & $0.087 \mathrm{bAB}$ & $0.047 \mathrm{cBC}$ & $0.059 \mathrm{cB}$ & $0.172 \mathrm{aA}$ \\
3 & $0.087 \mathrm{bAB}$ & $0.047 \mathrm{cBC}$ & $0.059 \mathrm{cB}$ & $0.172 \mathrm{aA}$ \\
6 & $0.060 \mathrm{aC}$ & $0.060 \mathrm{aBC}$ & $0.068 \mathrm{aB}$ & $0.060 \mathrm{aC}$ \\
9 & $0.067 \mathrm{aBC}$ & $0.061 \mathrm{aB}$ & $0.054 \mathrm{aBC}$ & $0.058 \mathrm{aC}$ \\
12 & $0.092 \mathrm{bA}$ & $0.112 \mathrm{abA}$ & $0.110 \mathrm{bA}$ & $0.133 \mathrm{aB}$ \\
15 & $0.033 \mathrm{aD}$ & $0.037 \mathrm{aC}$ & $0.036 \mathrm{aC}$ & $0.028 \mathrm{aD}$ \\
\hline
\end{tabular}

Different lowercase letters in line significantly different between themselves and capital letters indicate significant differences between the columns using the Tukey test at $5 \%$ probability. 


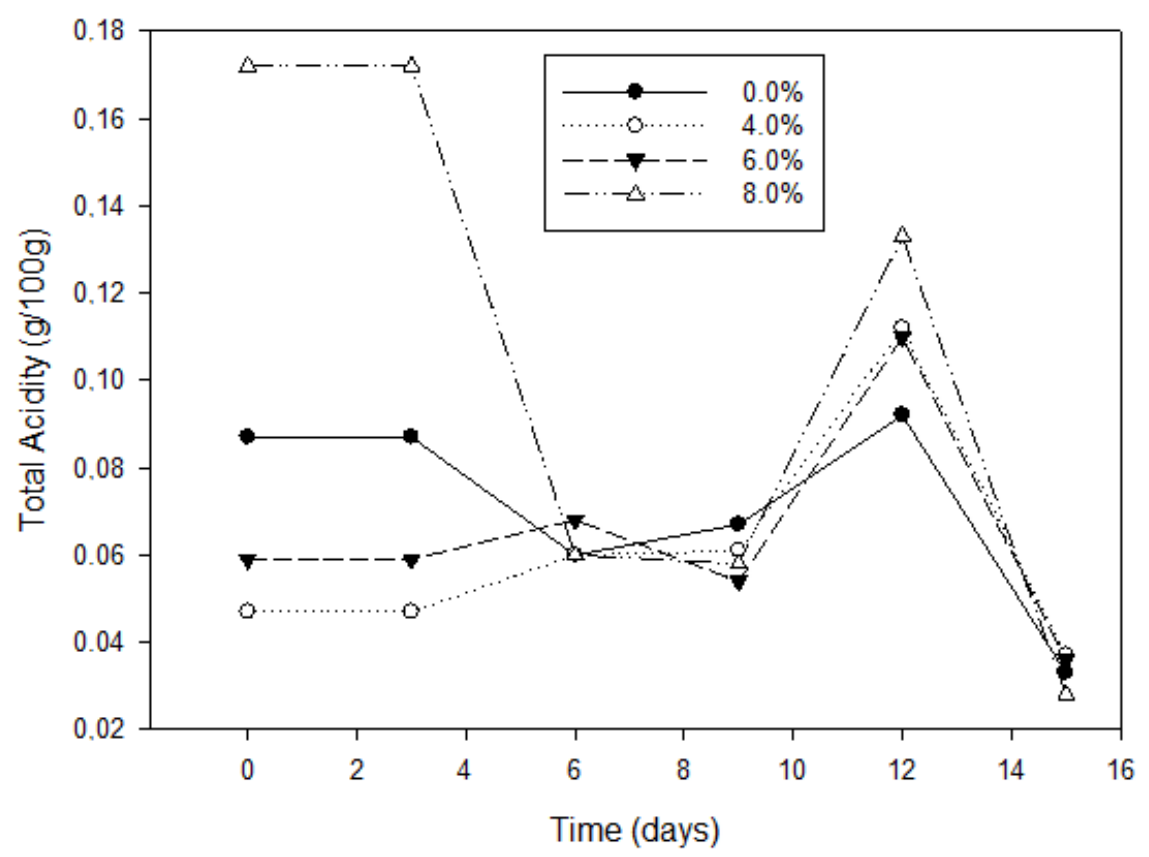

Figure 2. Titratable acidity levels for control and treatment during storage of mangaba fruits.

Table 3. Vitamin $\mathrm{C}$ contents of mangaba fruits stored in BOD at temperature of $22 \pm 1^{\circ} \mathrm{C}$ and coated with pectin solution.

\begin{tabular}{ccccc}
\hline \multirow{2}{*}{ Days of storage } & \multicolumn{4}{c}{ Pectin solution concentration } \\
\cline { 2 - 5 } & $\mathbf{0} \%$ & $\mathbf{4 \%}$ & $\mathbf{6 \%}$ & $\mathbf{8 \%}$ \\
\hline 0 & $154.59 \mathrm{aBC}$ & $149.90 \mathrm{aBC}$ & $154.59 \mathrm{aB}$ & $166.73 \mathrm{aA}$ \\
3 & $154.59 \mathrm{aBC}$ & $149.90 \mathrm{aBC}$ & $154.59 \mathrm{aB}$ & $166.73 \mathrm{aA}$ \\
6 & $203.52 \mathrm{aAB}$ & $232.48 \mathrm{aA}$ & $228.56 \mathrm{aA}$ & $203.52 \mathrm{aA}$ \\
9 & $143.24 \mathrm{aC}$ & $170.64 \mathrm{aBC}$ & $149.51 \mathrm{aB}$ & $168.29 \mathrm{aA}$ \\
12 & $215.26 \mathrm{aA}$ & $204.30 \mathrm{aAB}$ & $203.52 \mathrm{aAB}$ & $207.43 \mathrm{aA}$ \\
15 & $135.42 \mathrm{aC}$ & $133.07 \mathrm{aC}$ & $177.68 \mathrm{aAB}$ & $163.59 \mathrm{aA}$ \\
\hline
\end{tabular}

Different lowercase letters in line significantly different between themselves and capital letters indicate significant differences between the columns using the Tukey test at $5 \%$ probability.

fruits and 4 and $6 \%$ pectin treatments. However, for all concentrations, reduction in acidity levels was observed in the sixth and ninth day of storage, increase in the twelfth day and reduction again on the last day of the analyses.

\section{Vitamin C levels}

Table 3 shows that vitamin $\mathrm{C}$ content during the storage of mangaba fruits ranged from 133.07 to $232.48 \mathrm{mg}$ of ascorbic acid per $100 \mathrm{~g}$ of fruit. There were no significant differences among treatments in vitamin C contents. However, during the days that mangaba fruits remained stored, differences in the ascorbic acid quantification among fruits coated with the same pectin concentration were observed.

Mangaba fruits stored in BOD and coated with pectin showed an increase and subsequent decrease in vitamin C content, as shown in Figure 3. In studies with "citrus" during storage, a decrease in the amount of vitamin $C$ (Malgarin et al., 2008) due to ripening was observed. This indicates the onset of fruit quality loss.

\section{Turgor pressure levels}

There were variations in the turgor pressure levels of 


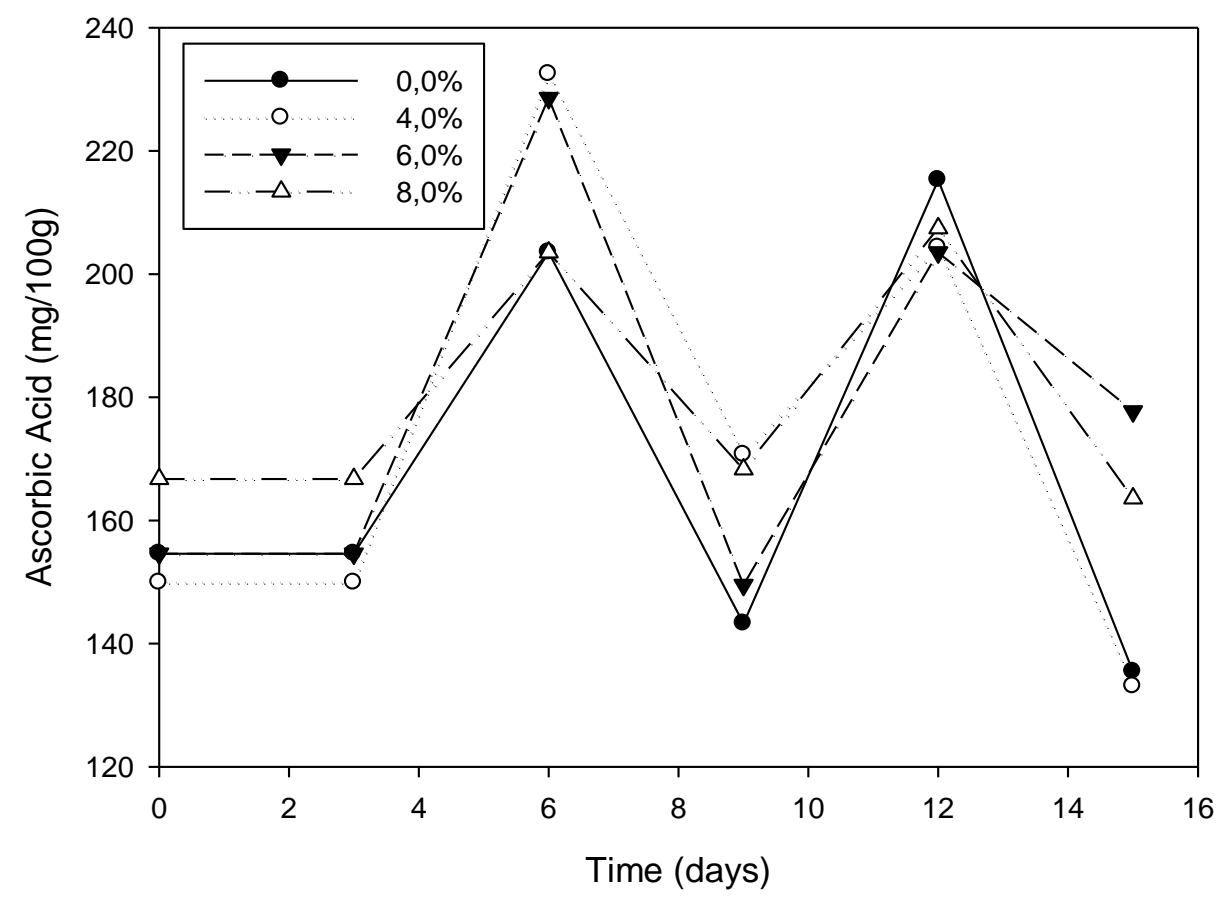

Figure 3. Ascorbic acid (vitamin C) levels for control and treatment during storage of mangaba fruits.

Table 4. Turgor pressure levels of mangaba fruits stored in $B O D$ at temperature of $22 \pm 1^{\circ} \mathrm{C}$ and coated with pectin solution.

\begin{tabular}{ccccc}
\hline \multirow{2}{*}{ Days of storage } & \multicolumn{4}{c}{ Pectin solution concentration } \\
\cline { 2 - 5 } & $\mathbf{0 \%}$ & $\mathbf{4 \%}$ & $\mathbf{6 \%}$ & $\mathbf{8 \%}$ \\
\hline 0 & $0.120 \mathrm{aB}$ & $0.140 \mathrm{aA}$ & $0.124 \mathrm{aA}$ & $0.177 \mathrm{aA}$ \\
3 & $0.119 \mathrm{aB}$ & $0.139 \mathrm{aA}$ & $0.110 \mathrm{aA}$ & $0.177 \mathrm{aA}$ \\
6 & $0.246 \mathrm{aA}$ & $0.072 \mathrm{bAB}$ & $0.069 \mathrm{bA}$ & $0.068 \mathrm{bB}$ \\
9 & $0.047 \mathrm{aB}$ & $0.047 \mathrm{aB}$ & $0.046 \mathrm{aA}$ & $0.063 \mathrm{aB}$ \\
12 & $0.039 \mathrm{aB}$ & $0.038 \mathrm{aB}$ & $0.039 \mathrm{aA}$ & $0.034 \mathrm{aB}$ \\
15 & $0.039 \mathrm{aB}$ & $0.038 \mathrm{aB}$ & $0.039 \mathrm{aA}$ & $0.034 \mathrm{aB}$ \\
\hline
\end{tabular}

Different lowercase letters in line significantly different between themselves and capital letters indicate significant differences between the columns using the Tukey test at $5 \%$ probability.

stored mangaba fruits. Table 4 illustrates that at the end of the storage period, there was no improvement in the firmness of mangaba fruits treated compared to control fruits.

Cell turgor is the compressive force which can be represented by measuring fruit peel firmness (Luengo et al., 2003). Figure 4 shows that fruits coated with pectin present results similar to those of untreated mangaba fruits.

\section{Fruit color}

Table 5 shows the change in $L^{*}$ parameter, indicating that the luminosity of the sample ranges from 0 (completely dark) to 100 (completely clear) for the storage of mangaba fruits.

The differences in $L^{*}$ parameter analyzed for mangaba fruitscoated with pectin are seen in Figure 5. As expected, fruits showing darker coloration and greater deterioration were uncoated fruits (control).Table 6 shows the changes in $a^{*}$ parameter; its lower and even negative values indicate green coloration but the higher values of $a^{*}$ parameter indicate red-purple coloration.

Not fully ripe mangaba fruits showed slightly reddish coloration at the beginning of analyses, except for fruits with $8 \%$ pectin. During storage, uncoated fruits and those with 4 and $6 \%$ coating tended to show reddish coloration, 


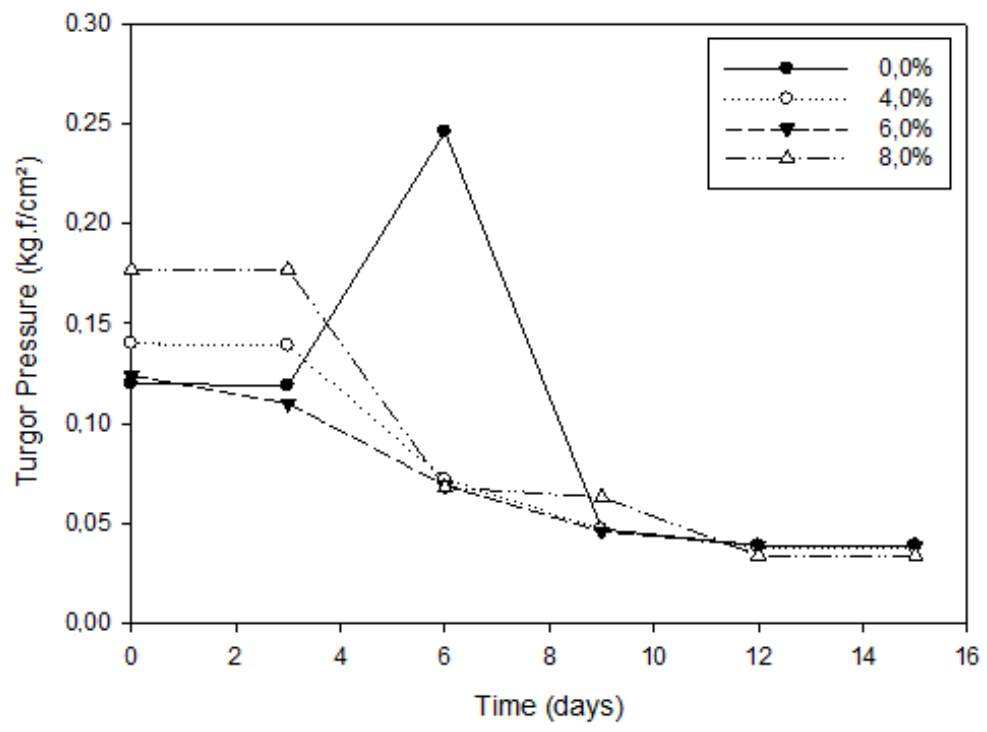

Figure 4. Turgor pressure values for control and treatments during storage of mangaba fruits.

Table 5. $L^{*}$ parameter during storage of coated mangaba fruits.

\begin{tabular}{ccccc}
\hline \multirow{2}{*}{ Days of storage } & \multicolumn{4}{c}{ Pectin solution concentration } \\
\cline { 2 - 5 } & $\mathbf{0} \%$ & $\mathbf{4} \%$ & $\mathbf{6 \%}$ & $\mathbf{8 \%}$ \\
\hline 0 & $39.81 \mathrm{bB}$ & $40.04 \mathrm{bB}$ & $33.12 \mathrm{bB}$ & $51.06 \mathrm{aA}$ \\
3 & $42.40 \mathrm{aAB}$ & $39.61 \mathrm{aB}$ & $39.28 \mathrm{aAB}$ & $47.68 \mathrm{aA}$ \\
6 & $48.42 \mathrm{aAB}$ & $50.04 \mathrm{aA}$ & $48.54 \mathrm{aA}$ & $50.62 \mathrm{aA}$ \\
9 & $45.41 \mathrm{aAB}$ & $48.11 \mathrm{aAB}$ & $40.75 \mathrm{aAB}$ & $47.17 \mathrm{aA}$ \\
12 & $44.26 \mathrm{aAB}$ & $47.88 \mathrm{aAB}$ & $47.71 \mathrm{aA}$ & $46.41 \mathrm{aA}$ \\
15 & $50.82 \mathrm{aA}$ & $49.60 \mathrm{aA}$ & $42.28 \mathrm{aAB}$ & $48.28 \mathrm{aA}$ \\
\hline
\end{tabular}

Different lowercase letters in line significantly different between themselves and capital letters indicate significant differences between the columns using the Tukey test at $5 \%$ probability.

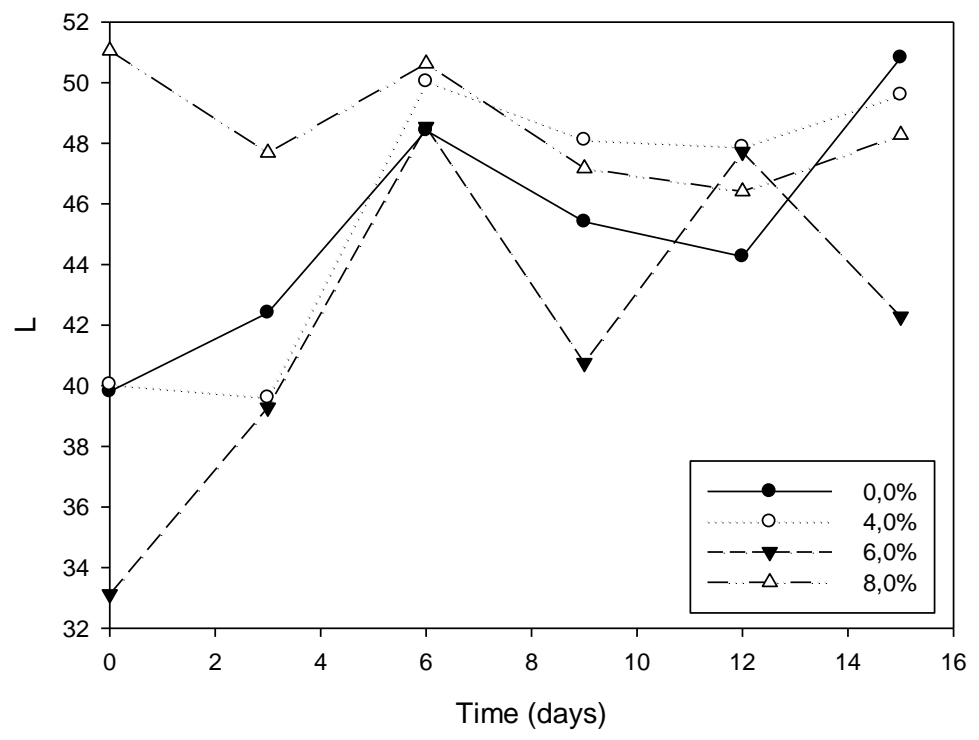

Figure 5. $L^{*}$ parameter for control and treatment during storage of mangaba fruits. 
Table 6. $a^{\star}$ parameter during storage of coated mangaba fruits.

\begin{tabular}{ccccc}
\hline \multirow{2}{*}{ Days of storage } & \multicolumn{4}{c}{ Pectin solution concentration } \\
\cline { 2 - 5 } & $\mathbf{0 \%}$ & $\mathbf{4 \%}$ & $\mathbf{6 \%}$ & $\mathbf{8 \%}$ \\
\hline 0 & $-21.48 \mathrm{bA}$ & $-19.15 \mathrm{abA}$ & $-13.98 \mathrm{aA}$ & $-25.30 \mathrm{bBC}$ \\
3 & $-20.48 \mathrm{aA}$ & $-21.76 \mathrm{aA}$ & $-20.01 \mathrm{aA}$ & $-16.58 \mathrm{aA}$ \\
6 & $-21.10 \mathrm{aA}$ & $-20.06 \mathrm{aA}$ & $-18.29 \mathrm{aA}$ & $-20.08 \mathrm{aABC}$ \\
9 & $-21.12 \mathrm{abA}$ & $-24.55 \mathrm{abA}$ & $-17.49 \mathrm{aA}$ & $-26.32 \mathrm{bC}$ \\
12 & $-21.85 \mathrm{aA}$ & $-18.52 \mathrm{aA}$ & $-19.40 \mathrm{aA}$ & $-21.39 \mathrm{aABC}$ \\
15 & $-20.02 \mathrm{aA}$ & $-25.26 \mathrm{aA}$ & $-20.42 \mathrm{aA}$ & $-18.01 \mathrm{aAB}$ \\
\hline
\end{tabular}

Different lowercase letters in line significantly different between themselves and capital letters indicate significant differences between the columns using the Tukey test at $5 \%$ probability.

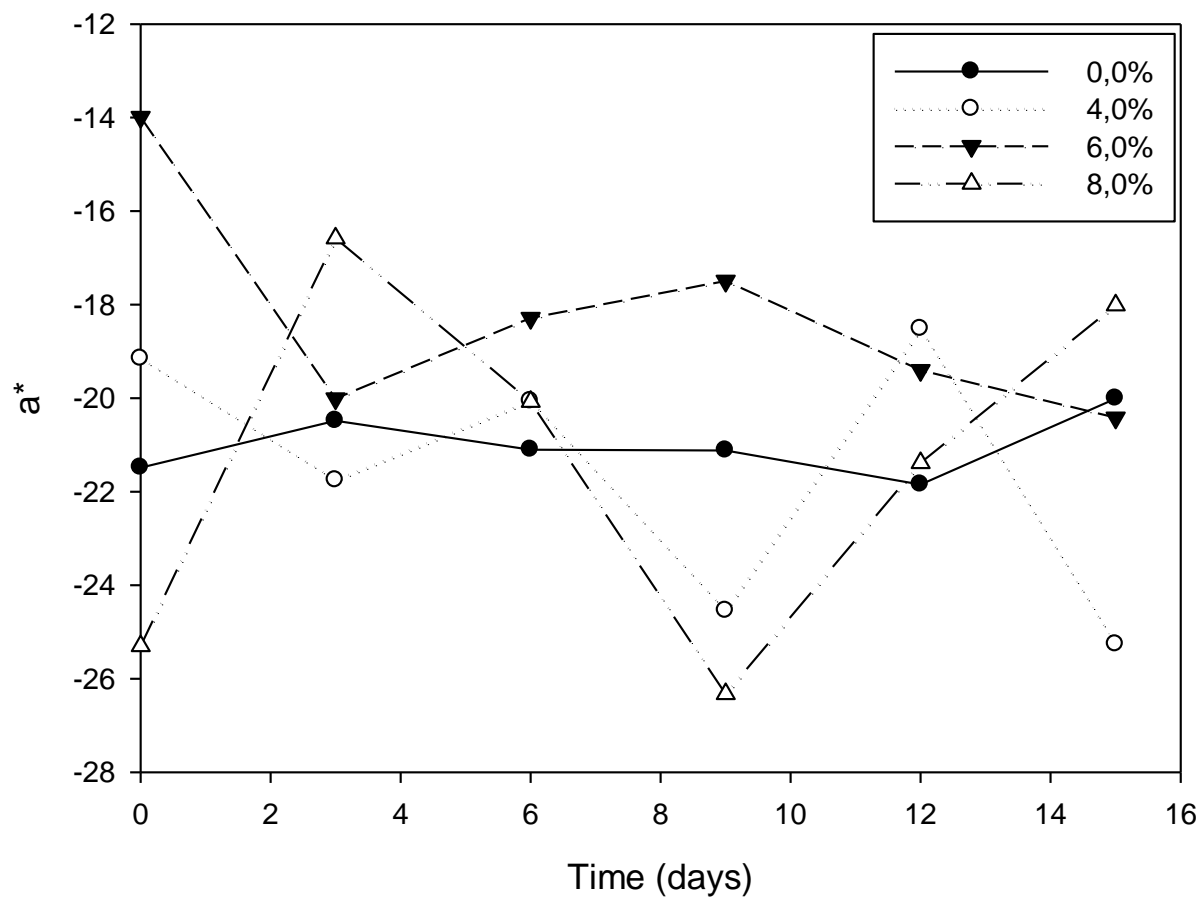

Figure 6. $a^{*}$ parameter for control and treatment during storage of mangaba fruits.

which confirms that fruits have undergone ripening process. However, fruits with $8 \%$ coating showed only slight red coloration at the end of the experiment.

It was found that the $a^{*}$ parameter showed great variations during storage of mangaba fruits (Figure 6). Fruits coated with $4 \%$ pectin resulted in large variations while fruits coated with $0 \%$ pectin showed lower colour variation in the pattern analysis and during the study period.

Table 7 shows the changes in $b^{*}$ parameter; its lower and negative values indicate blue coloration but the higher values of this parameter indicate yellowish coloration.

There was an increase in yellowish coloration of fruits up to the sixth day of storage. Fruits with $8 \%$ pectin coating had a decrease in yellow colour on the third day and an increase on the sixth day of storage. Fruits with $6 \%$ pectin increased yellowish coloration after 12 days of storage; however, a decrease was observed after this period, as well as for the other pectin concentrations. Lower yellowish coloration values indicate that the fruit maintained quality during storage.

Figure 7 shows that coated and uncoated mangaba fruits showed no traits of blue colour during ripening. However, yellow colour showed considerable variation in fruits with $6 \%$ pectin coating. At the end of the analysis, mangaba fruits coated with 0 and $4 \%$ pectin showed higher values for the $b^{*}$ parameter, a fact that indicates greater maturity of these fruits when compared to mangaba fruits with 6 and $8 \%$ pectin coating. 
Table 7. $b^{\star}$ parameter during storage of coated mangaba fruits.

\begin{tabular}{ccccc}
\hline \multirow{2}{*}{ Days of storage } & \multicolumn{4}{c}{ Pectin solution concentration } \\
\cline { 2 - 5 } & $\mathbf{0} \%$ & $\mathbf{4} \%$ & $\mathbf{6 \%}$ & $\mathbf{8} \%$ \\
\hline 0 & $40.60 \mathrm{bA}$ & $40.27 \mathrm{bA}$ & $31.64 \mathrm{cB}$ & $49.52 \mathrm{aA}$ \\
3 & $42.83 \mathrm{aA}$ & $40.60 \mathrm{aA}$ & $39.31 \mathrm{aAB}$ & $41.85 \mathrm{aA}$ \\
6 & $44.96 \mathrm{aA}$ & $46.25 \mathrm{aA}$ & $43.99 \mathrm{aA}$ & $47.11 \mathrm{aA}$ \\
9 & $42.63 \mathrm{aA}$ & $43.66 \mathrm{aA}$ & $37.40 \mathrm{aAB}$ & $44.96 \mathrm{aA}$ \\
12 & $40.22 \mathrm{aA}$ & $39.58 \mathrm{aA}$ & $41.20 \mathrm{aA}$ & $44.41 \mathrm{aA}$ \\
15 & $47.18 \mathrm{aA}$ & $48.69 \mathrm{aA}$ & $38.63 \mathrm{bAB}$ & $41.02 \mathrm{abA}$ \\
\hline
\end{tabular}

Different lowercase letters in line significantly different between themselves and capital letters indicate significant differences between the columns using the Tukey test at $5 \%$ probability.

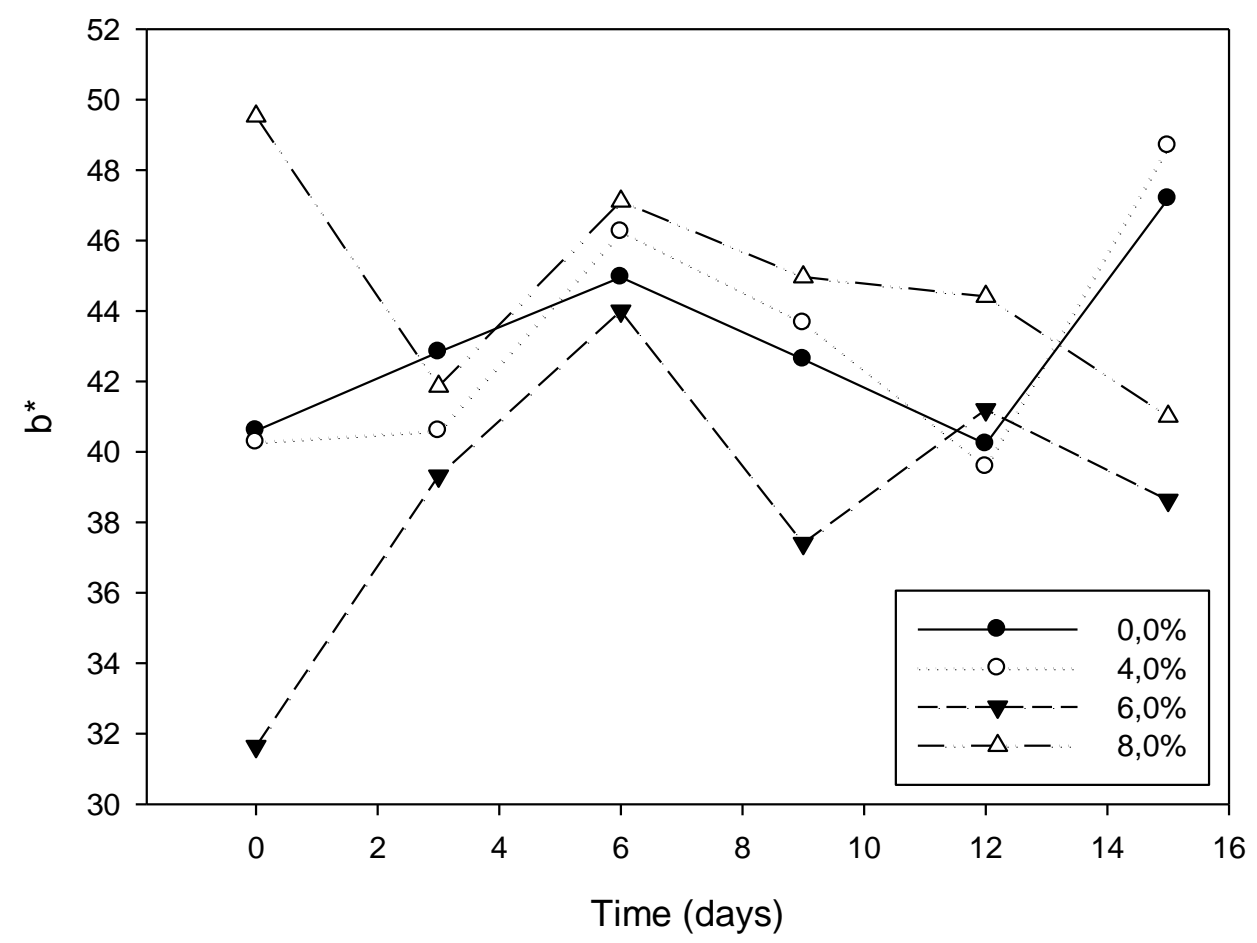

Figure 7. $b^{\star}$ parameter for control and treatment during storage of mangaba fruits.

\section{Scanning electron microscopy}

The physical structure of control mangaba fruits coated with 4,6 and $8 \%$ pectin and scanned under SEM is shown in Figures 8, 9, 10 and 11.

\section{DISCUSSION}

\section{Soluble solids content}

The soluble solids content ranged from 8.72 to 17.14 ${ }^{\circ}$ Brix for mangaba fruits in this study. These values are lower than those found by Cohen and Sano (2010), from 17.7 to $20.3{ }^{\circ}$ Brix, who studied the physicochemical parameters of mangaba fruits. The values of the mangaba fruits kept at room temperature having yellow and red pigments on the shell without the use of biofilms ranged from 11 to $15^{\circ}$ Brix (Santos et al., 2009).

Mangaba fruits analyzed by Santos et al. (2009) showed an increase in SS contents during storage in modified atmosphere and ambient atmosphere. Mangaba is a climacteric fruit; therefore, the soluble solids content increases with maturation. This fact is related to the biosynthesis of soluble sugars or polysaccharides degradation (Kays, 1997). Bashir and Abu-Goukh (2003) 

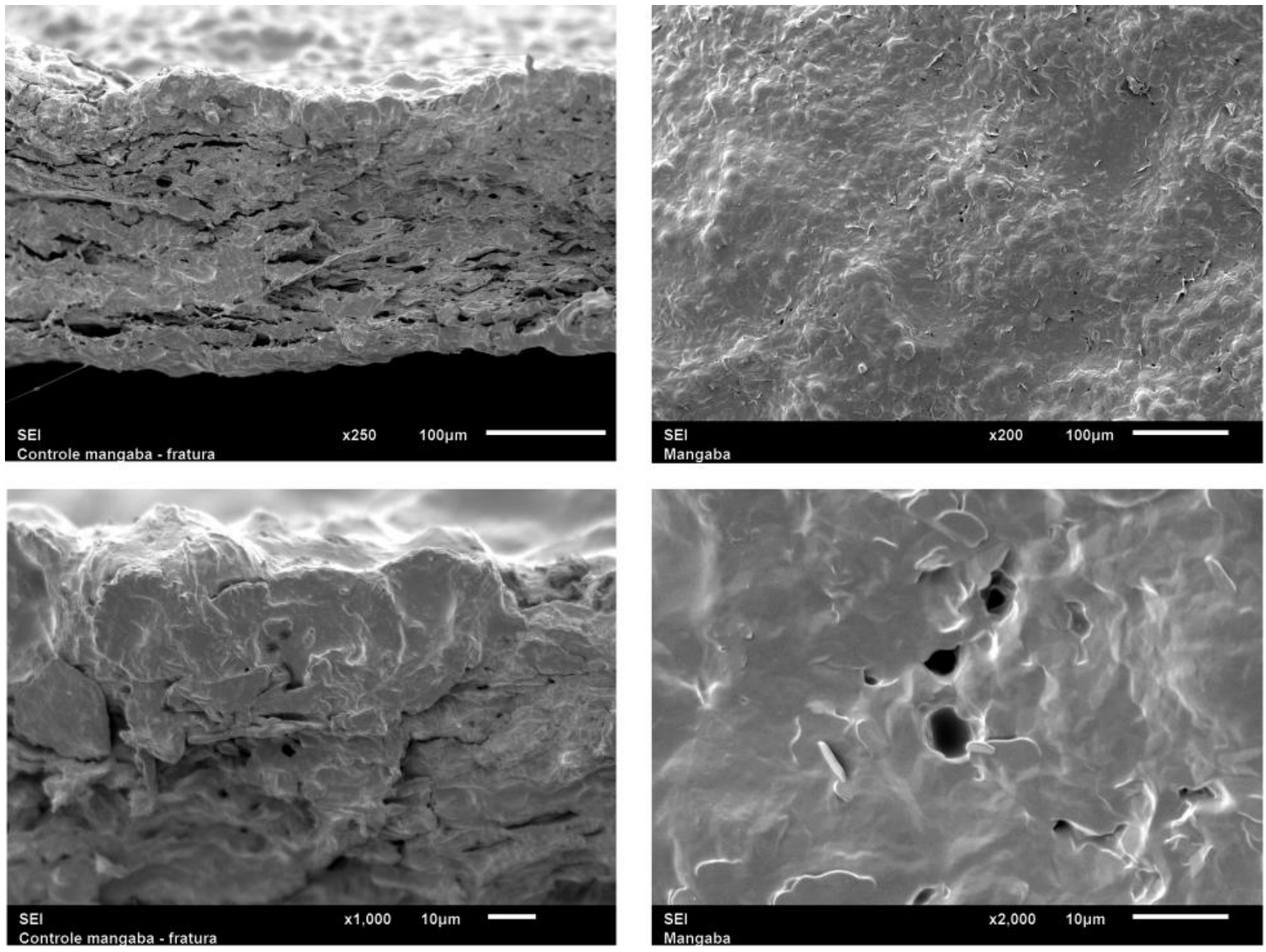

Figure 8. Physical structure (SEM) of control mangaba fruits (Hancornia speciosa Gomes). Cross-section at the left and fruit surface at the right.

reported that the increased sugar content is a climacteric peak phenomenon and after this, there is a reduction in soluble solids content. Fruits coated with $4 \%$ pectin were at climacteric peak at the beginning of analyses; however, the other treatments have gone through this phenomenon only at the $12^{\text {th }}$ day, confirming maintenance of fruit quality.

However, Jerônimo and Kanesiro (2000) indicate that such peaks may be the result of the transformation of reserves accumulated during formation and development of solid into soluble sugars.

\section{Titratable acidity levels}

Mangaba fruits stored at room and refrigeration temperature $\left(11^{\circ} \mathrm{C}\right.$ ) with ethylene incorporation (Campos et al. (2011) showed values between 0.554 and $0.840 \mathrm{~g}$ citric acid/100 g of pulp. Santos et al. (2009) reported no significant variations in the titratable acidity levels of mangaba fruits during storage and determined values greater than $1.5 \%$. Soares Junior et al. (2008) found mean values of 0.38 and $0.78 \%$ for mangabas fruits stored at room and refrigeration temperature with the use of PVC and PE film.

The increased titratable acidity levels on the twelfth day of storage of mangaba fruits can be related to the onset of anaerobic respiration that causes physiological disorders in fruits. Anaerobic respiration is the result of the low permeability of the biofilm to gases, causing fruits to obtain energy; through this process it produces acetaldehyde and ethanol, affecting the quality of the product (Steffens et al., 2007; Petracek et al., 2002). However, according to Scalon et al. (2012), the unexpected increase in the acidity levels may also be related to release of galacturonic acids from the cell wall by the action of pectin methyl esterase and polygalacturonase enzymes. 

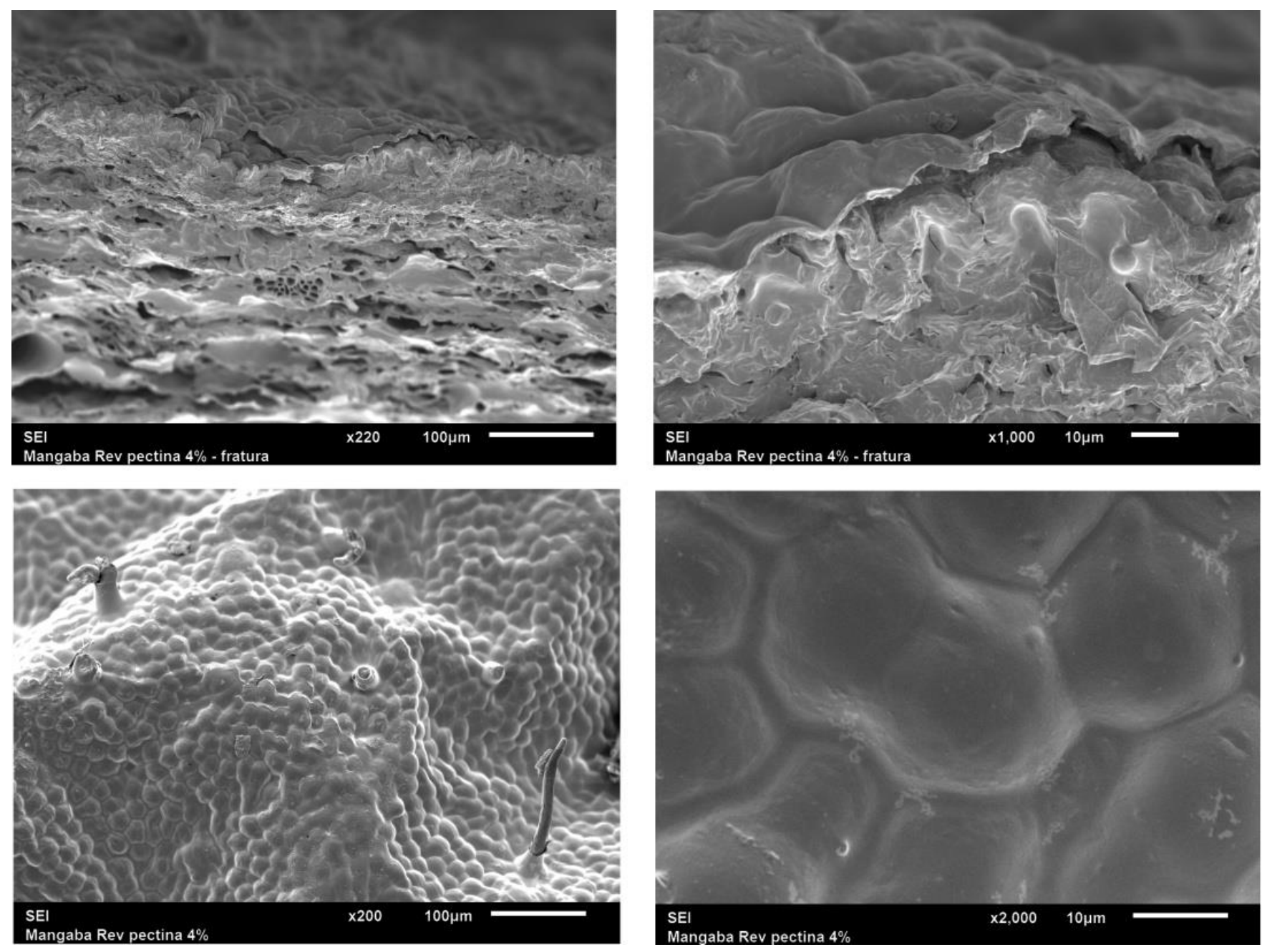

Figure 9. Physical structure (SEM) of mangaba fruits (Hancornia speciosa Gomes) with $4 \%$ pectin. Cross-section at the left and fruit surface at the right.

The increase in acidity levels is a result of the production of substrates during respiration of mangaba fruits and pectin hydrolysis rates present in the cell wall of fruits (Borges et al., 2000). However, the last day of storage at low temperature may have contributed to a decrease in respiratory rates, which contributed to the drop in titratable acidity levels. Souza et al. (2007) reported that this behavior occurred in mangaba clones when their physicochemical characteristics were analyzed.

\section{Vitamin C levels}

For mangaba fruits kept at room temperature and under refrigeration using ethylene, Campos et al. (2011) determined values between 132.60 and $166.49 \mathrm{mg}$ ascorbic acid / $100 \mathrm{~g}$. It was reported that mangaba clones had average of 164.77-188.75 mg ascorbic acid / $100 \mathrm{~g}$ pulp (Souza et al., 2007).
Carnelossi et al. (2004) reported that some fruits can retain and increase the ascorbic acid content during storage. Carnelossi et al. (2009) reported behavior similar to this work with mangaba fruits stored at different temperatures. There are decreases in vitamin $\mathrm{C}$ contents in tropical fruits during storage, according to some authors (Klein, 1987; Favell, 1998; Melo et al., 2000). Vitamin $C$ acts as an antioxidant and increases in its content during storage could be related to the progress of oxidative reactions in the process of fruit ripening (Carnelossi et al., 2009).

\section{Turgor pressure levels}

On the sixth day of analysis, control fruits showed a peak in turgor pressure values; however, on the ninth day of analysis, fruits showed a considerable decrease in this parameter. This decrease can be related to the ripening of fruits that leads to a series of enzymatic reactions 

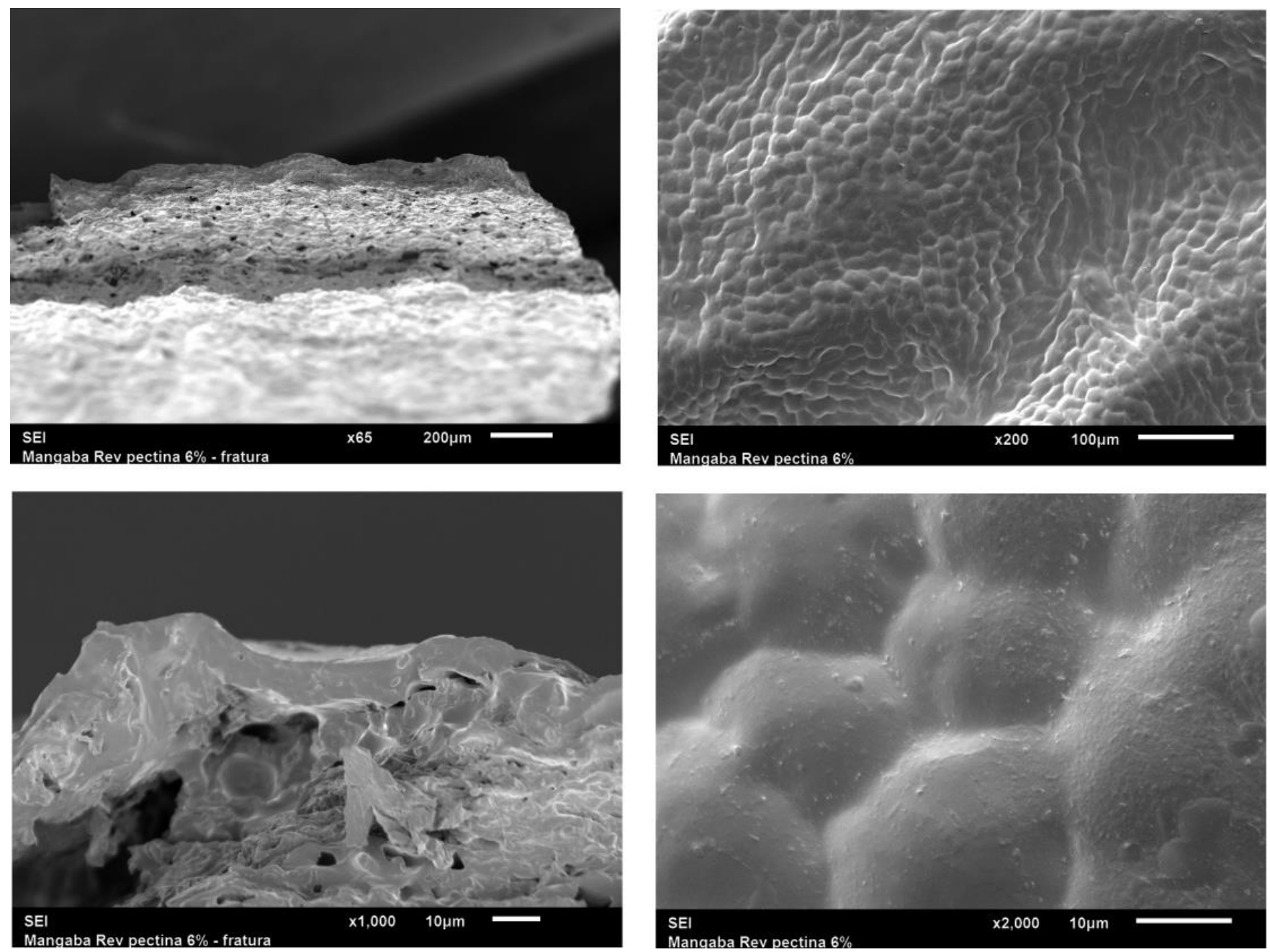

Figure 10. Physical structure (SEM) of mangaba fruits (Hancornia speciosa Gomes) with $6 \%$ pectin. Cross-section at the left and fruit surface at the right.

resulting from climacteric respiration and ethylene production (Castricini, 2009). During ripening, the conversion of insoluble pectin into soluble pectin causes a decrease in fruit resistance, which could have contributed to the fact that coated fruit did not maintain turgor pressure during storage (Chitarra and Chitarra, 2005).

However, mangaba fruits stored under modified atmosphere showed lower loss of firmness due to reduced losses of fresh weight (Santos et al., 2009). According to Carnelossi et al. (2009), mangaba fruits kept under constant refrigeration showed better results in relation to cell wall firmness.

The use of coating contributes to greater structural integrity and physical strength of fruits, increased resistance when used in mixing and physical impacts during transport, helps to lower microbiological contamination rates and also contributes to maintaining the appearance of the product (Matuška et al., 2006). However, pectin substances that compose the cell wall of fruits are responsible for degrading pectin macro-molecules, a factor that may have contributed to the degradation of mangaba fruit coated with pectin (Chitarra and Chitarra, 2005).

\section{Fruit colour}

At the beginning of analyses, mangaba fruits showed median brightness values. Throughout the storage period, fruits were getting darker, except for fruits with $8 \%$ pectin, which were clearer at the end of the analysis.

The darker the fruit, the greater its deterioration. In general, mangaba fruits became clearer throughout the storage period, and browning occurred only at the ninth and twelfth days of storage. Except for mangaba fruits coated with $6 \%$ pectin, which became dark only after the end of the experiment, fruits were clear, showing that 

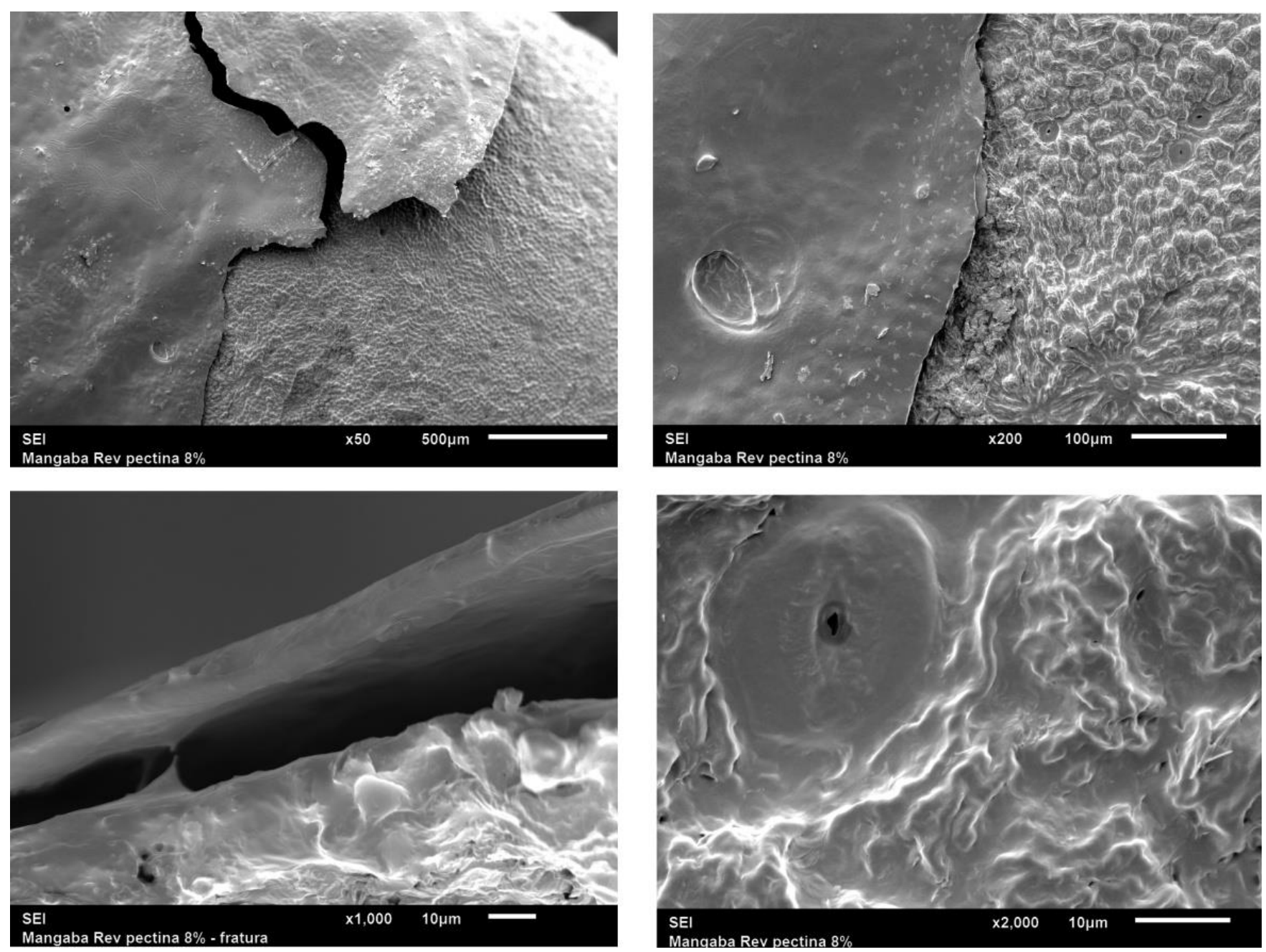

Figure 11. Physical structure (SEM) of mangaba fruits (Hancornia speciosa Gomes) with $8 \%$ pectin. Cross-section at the left and fruit surface at the right.

coating helped their conservation.

Lima (2011) found that mangaba fruits stored at temperatures of 6 and $0^{\circ} \mathrm{C}$ showed injuries caused by cold and there were no significant differences in brightness from mangaba fruits stored at $12^{\circ} \mathrm{C}$. Toledo et al. (2003) reported that fallen mangaba fruits presented good appearance up to seven days of storage. However, not fully ripe fruits maintained their quality up to nine days of storage at temperature of $6^{\circ} \mathrm{C}$.

The quality of a food is related to taste, odor, colour and texture. Cardoso et al. (1997) reported that colour is visual perception in the interaction of light with the object and is one of the most important attributes for product acceptance. Frequently, it is more important than flavour and odor. Lima (2011) confirmed that stored mangaba fruits and those harvested when not fully ripe showed more intense reddish coloration due to ripening, which does not determine that the fruits suffered losses in their sensory quality.

\section{Scanning electron microscopy}

Analysis of mangaba fruits using scanning electron microscopy showed that the surface of uncoated fruits presents roughness and circular structures with the incidence of open spots, which makes fruits perishable and easily invaded by microorganisms.

With the use of coating, the cell wall of mangaba fruits became more uniform, but fruits coated with 6 and $8 \%$ pectin presented circular structures on the surface, which may be possible air microbubbles. This may contribute to increased permeability of the surface to water vapor and gases, causing loss of moisture and darkening (Fontes, 2005). Furthermore, at high concentration (8\% pectin), coating has considerable thickness, which makes the film brittle, causing losses in product quality.

Scanning electron microscopy is important to evaluate the morphology of films through detailed images of their surface (Freire et al., 2009). When biofilm is used for fruit 
coating, microscope can provide information on the product miscibility (Wang and Composto, 2003).

Biofilm preparation is essential because the film drying process and the nature of the hydrocolloid make components such as polysaccharides, plasticizers and water to arrange in different ways (Meneguim, 2012).

\section{Conclusion}

The storage of mangaba fruits with pectin biofilm and controlled temperature increased their shelf life up to the sixth day of storage. Later, the decrease in vitamin C content, titratable acidity and turgor pressure confirms that the fruits have undergone ripening process. However, SS contents increased during the study for control fruits and those treated with 6 and $8 \%$ film solution, confirming the conservation of this parameter. The colour of fruits with 6 and $8 \%$ coating did not change significantly and indicated that at these concentrations, fruits maintained their visual qualities. Scanning electron microscopy indicates that coating with $2 \%$ pectin contributed to smoother and more consistent surface.

\section{Conflict of interests}

The authors did not declare any conflict of interest.

\section{ACKNOWLEDGEMENTS}

The authors would like to thank the Conselho Nacional de Desenvolvimento Científico e Tecnológico (CNPq) and the Fundação de Apoio a Pesquisa do Estado de Goiás (FAPEG) for financial support for this project and Coordenação de Aperfeiçoamento de Pessoal de Nível Superior (CAPES) for post-doctoral scholarship granted to the first and fourth authors.

\section{REFERENCES}

AOAC (1992). Official methods of analysis of the Association of the Agricultural Chemists. 12 ed. Washington, 1992.

AOAC (2000). OfficialMethodsofAnalysisof AOAC International. $17^{\text {th }}$. v. II., 2000.

Bashir HA, Abu-Goukh AA (2003). Compositional changes during guava fruit ripening. Food Chem. 80(1):557-561.

Borges MF, Filgueiras HAC, Moura CFH. (2000). Mangaba (HancorniaspeciosaGomes). In: Alves RE, Filgueiras HAC, Moura CFH. (Ed.). Caracterização de frutas nativas da América do Sul. Jaboticabal: Funep, 44-45.

Calbo AG, Nery AA (1995). Firmly measure in vegetables by the technique of flattening. Hortic. Bras. 12(1):14-18.

Campos RP, Knoch B, Hiane PA, Ramos MIL, Ramos Filho MM (2011). 1 -MCP on Mangaba stored at ambienal temperature and $11^{\circ} \mathrm{C}$, Jaboticabal. 33(1): 206-212.

Cardoso RL, Ferreira VL, Montgomery MW, Yotsuyanagi K. (1997). Effect of time, light and temperature in the colour of red mountain apple jelly (Eugenia malaccensis L.). Ciênc. Tecnol. Aliment. 17(1):28-31.
Carnelossi MAG, Sena HC, Narain N, Yaguiu P, Silva GF (2009). Physico-chemical quality changes in mangaba (Hancorniaspeciosa Gomes) fruit stored at different temperatures. Braz. Arch. Biol. Technol. 52(4): 985-990.

Carnelossi MAG, Toledo WFF, Souza DCL, Lira ML, Silva GF, Jalali VRR, Viégas PRA. (2004). Postharvest conservation of mangaba (Hancornia speciosa Gomes). Rev. Ciênc. Agrotec. 28(5):1119-1125.

Castricini A (2009). Aplicação de Revestimentos Comestíveis para Conservação de Mamões (Caricapapaya L.) 'Golden'. 2009. 35 f. Tese (Doutorado em Fitotecnia) - Instituto de Agronomia - Curso de Pós-Graduação em Fitotecnia, Universidade Federal Rural do Rio de Janeiro, Serópedica.

Chitarra MIF, Chitarra AB (2005). Pós-colheita de frutas e hortaliças: fisiologia e manuseio.2 ed. Lavras: UFLA. 783p.

Cohen KDO, Sano SM (2010). Physical and chemical parameters of fruit Mangabeira. Electronic version. EMBRAPA: Planaltina, 2010. Available at: <www.cpac.embrapa.br/download/1725/t>. Access in: January 2014.

Corrêa SJP (2011). Utilização de filmes a base de pectina contendo extrato de própolis vermelha para recobrimento de sementes de girassol. Abril, 2011. 79 f. Tese - Universidade de Tiradentes, Programa de Pós- Graduação em Saúde e Ambiente, Aracaju. 2011.

Favell DJ (1998). A comparison of the vitamin C contente of fresh and frozen vegetables. Food Chem. 62(1):59-64.

Fontes LCB (2005). Uso de solução conservadora e de películas comestíveis em maçãs da cultivar Royal Gala minimamente processadas: efeito na fisiologia e conservação. 2005. Dissertação (mestrado em Ciência e Tecnologia de Alimentos) - Escola Superior de Agricultura Luiz de Queiroz, Piracicaba, 2005. 118 p.

Freire AC, Podczeck F, Veiga F, Sousa J (2009). Starch-based coatings for colon-specific delivery. Part II: Physicochemical properties and in vitro drug release from high amylose maize starch films. Eur. J. Pharm. Biopharm. 72(3):587-594.

Ganga RMD, Ferreira GA, Chaves LJ, Naves RV, Nascimento JL. (2010). Characterization of fruits and trees from natural population of Hancornia speciosa Gomes of cerrado Rev. Bras. Frutic. 32(1):101-113.

Jerônimo EM, Kanesiro MAB (2000). Storage association effect of refrigerated and modified atmosphere in the quality of mangoes 'Palmer'. Rev. Bras. Frutic. 22(2):237-243.

Kays SJ (1997). Postharvest Physiology of Perishable Plant Products. Athens: Exon Press. 532p.

Klein BP (1987). Nutritional consequences of minimal processing of fruits and vegetables. J. Food Qual. 10:179-93.

Lima JP (2011). Qualidade pós-colheita, atividade antioxidante "in vitro" e perfil volatil da mangaba (Hancornia speciosa) submetida à refrigeração e atmosfera modificada.Dissertação (mestradoem Ciências de Alimentos) - Universidade Federal de Lavras, Lavras, 2011. 194p.

Luengo RFA,Calbo AG, Jacomino AP, Pessoa JDC (2003). Firmness of vegetables and fruits as a determinator of the maximum allowable pile height in commercialization packages. Hortic. Bras. 21(4):704707.

Machado LL, Ramos MLG, Caldas LS, Vivaldi LJ (2004). Selection of parents and clones of mangabeira for in vitro cultivation. Pesq. Agropec. Bras. 39(5): 431-435.

Malgarin MB,Cantillano RFF, Oliveira RP, Treptow RO (2008). Postharvest quality of the citrus fruit 'nova' in different cold storage and shelf life periods. Rev. Bras. Agrociência 14(1):19-23.

Matuska M, Lenart A, Lazarides HN (2006). On the use of edible coatings to monitor osmotic dehydration kinetics for minimal solids uptake. J. Food Eng. 72(1):85-91.

Melo EA, Lima VLAG, Nascimento P (2000). Storage Temperature and cherry. Sci. Agric. 57(4):629-634.

Meneguim AB (2012). Obtenção e caracterização de filmes de misturas de amido resistente e pectina como estratégia para liberação cólon específica de fármacos. 2012. Dissertação (Mestrado em Ciências Farmacêuticas) - Universidade Estadual Paulista, Araraquara, 2012. 99f.

Paiva EP, Lima MS, Paixão JA (2009). Chemical properties of these pectins. Revista Iberoamericana de Polímero 10(4):196-211.

Petracek PD, Joles DW, Shirazi A, Cameron AC (2002). Modified 
atmosphere packaging of sweet cherry (Prunusavium L., cv. 'Sams') fruit: metabolic responses to oxygen, carbondioxide, and temperature. Postharvest Biol. Technol. 24(3):259-270.

Sampaio TS, Nogueira PCL (2006). Volatile components of mangaba fruit(Hancornia speciosa Gomes) at three stages of maturity. Food Chem. 95(4):606-610.

Santos AFD, Silva SM, Mendonça RMN, Alves RE. (2009). Postharvest conservation of mangaba fruit as a function of maturity, atmosphere, and storage temperature. Ciênc. Tecnol. Aliment. 29(1):85-91.

Scalon SPQ, Oshiro AM, Dresch DM (2012). postharvest conservation of guavira (Campomanesia Adamantium Camb.) under different coating and temperatures of storage. Rev. Bras. Frutic. 34(4):10221029.

Soares DSC, Silva GF, Silva TCS, Nunes TP (2012). Half-ripe Mangaba (Hancorniaspeciosa Gomes) freezing kinetics with diferente diameters. Chem. Eng. Trans. 29:1411-1416.

Soares Júnior MS, Caliari M, Vera R, Guazzelli e Souza A. (2008). Postharvest conservation of mangaba fruit as a function of maturity, atmosphere, and storage temperature. Pesqui. Agropecu. Trop. 38(2):78-86.
Souza FG, Figueiredo RW, Alves RE, Maia GA, Araújo IA (2007). Postharvest quality of fruits from different mangabeira clones (Hancornia speciosa Gomes). Ciênc. Agrotecnol. 31(5): 1449-1454.

Steffens CA, Brackmann A, Lopes SJ, Pinto JAV, Eisermann AC, Giehl RFH, Webber A. (2007). Internal breakdown and respiration of 'Bruno'kiwifruit in relation to storage conditions. Cienc. Rural 37(6):1621-1626.

Toledo WFF, Toledo WFF, Souza DA, Carnelossi MAG, Silva GF. (2003). Thermal properties and water activity mangaba during cold storage. In: Simpósio Brasileiro sobre cultura da mangaba, 1. Aracaju, 2003. Anais... Aracaju: UFSE, 2003. CD-ROM.

Vieira Neto RD (2009). Tropical fruit growing: regional and exotic species. Brasília: EMBRAPA Informação Tecnológica: 338.

Wang $\mathrm{H}$, Composto RJ (2003). Wettingandphaseseparation in polymerblendfilms: Identificationof four thickness regimes withdistinctmorphologicalpathways. Interface Sci. 11:237-248. 